\title{
Challenges and Opportunities for Climate Change Education (CCE) in East Africa: A Critical Review
}

\author{
Abigael Apollo ${ }^{1, *}$ and Marcellus Forh Mbah ${ }^{2}$ \\ 1 Department of International Development, School of Arts and Humanities, Nottingham Trent University, \\ Nottingham NG1 4FQ, UK \\ 2 Institute of Education, School of Social Sciences, Nottingham Trent University, Nottingham NG1 4FQ, UK; \\ marcellus.mbah@ntu.ac.uk \\ * Correspondence: abigael.apollo2020@my.ntu.ac.uk
}

Citation: Apollo, A.; Mbah, M.F. Challenges and Opportunities for Climate Change Education (CCE) in East Africa: A Critical Review. Climate 2021, 9, 93. https:/ / doi.org/ 10.3390/cli9060093

Academic Editor: Thomas Beery

Received: 28 April 2021

Accepted: 2 June 2021

Published: 9 June 2021

Publisher's Note: MDPI stays neutral with regard to jurisdictional claims in published maps and institutional affiliations.

Copyright: (c) 2021 by the authors. Licensee MDPI, Basel, Switzerland. This article is an open access article distributed under the terms and conditions of the Creative Commons Attribution (CC BY) license (https:/ / creativecommons.org/licenses/by/ $4.0 /)$.

\begin{abstract}
It is undoubtedly clear that climate change is happening, and its adverse impacts could reverse the progress made toward meeting sustainable development goals. The global crisis poses one of the most severe challenges to reducing poverty and existing inequalities, especially in developing countries that are projected to be highly vulnerable to climate variability. However, the education sector provides an untapped opportunity for successful climate change adaptation and mitigation through knowledge and skill acquisitions, and consequently, positive behavioral change. Specifically, education can capacitate individuals and communities to make informed decisions and take practical actions for climate-resilient sustainable development. This study is focused on East Africa, a region whose economy heavily relies on climate-dependent activities. At present, East African governments are already embedding climate change in their school curriculum. However, they lack coherent approaches to leverage climate change education as a tool in their adaptation and mitigation strategies. Therefore, this review explores some of the critical barriers to climate change education and possible opportunities for leveraging learning to promote sustainable development in East Africa.
\end{abstract}

Keywords: climate change; education; East Africa; sustainable development

\section{Introduction}

Climate change is arguably one of the most pressing global issues that have long-term implications for all countries' sustainable development. From increasing shifting weather patterns that threaten food security to rising sea levels and extreme rainfall that cause catastrophic flooding, climate change impacts are wide-ranging and unprecedented in scale. Recent research warns that such extreme climate-related events could be worse than predicted in the near future [1-3]. At the root of the climate variability is global warming [1], mainly attributed to carbon-intensive industrialization and associated population growth, a key element in the current capitalist world that hampers green development initiatives. De Souza, et al. [4] assert that developing nations are particularly vulnerable to the impacts of climate change, even though they do not share the same burden of responsibility for global warming as the global north. Indeed, data from the Intergovernmental Panel on Climate Change (IPCC) support this argument, with the recent decadal analyses strongly pointing to increased warming trends across the African continent over the last 50 to 100 years [2].

In response to the climate change challenges mentioned above, nations have signed various global treaties to tackle the adverse impacts of climate change. The first agreement was the United Nations Convention on climate change, which was established during the earth summit in 1992 to prevent dangerous human interferences in the climate system [5]. The Kyoto Protocol, which launched negotiations to strengthen the global response to climate change, followed in 2008 with its implementation period ending in 2012. While the sum of the emission from countries that observed the Kyoto targets reduced significantly, 
Rosen [6] terms the protocol as the wrong solution at the right time due to its binding emission targets and short time frame for actions. Hence it resulted in improvident and unsubstantial impacts on the climate problem. Later, in 2015, the Paris Agreement on climate change was signed by all nations to accelerate and intensify the previous convention's actions. It seeks to enhance ambitious efforts to combat climate change while promoting developing countries' financial support to adapt to its effects [7]. While it is too early to assess the new climate deal's effectiveness, a debate on overarching inequality issues, such as carbon caps, climate finance, and the level of policy ambitions between developed and developing countries was vital [8]. Thus, such inequalities and power play in the climate problem pose significant challenges for unified and sustainable strategies against climate change.

\section{Contextual Background}

The East African region compromises of the countries of Djibouti, Kenya, Ethiopia, Tanzania, Rwanda, Sudan, South Sudan, Uganda, Eritrea, Burundi, and Somalia. According to the United Nations' latest data, East Africa's current population is around 400 million, and this number is estimated to double by 2050 [9]. Verburg, et al., Addaney and Weisser, et al. [10-12] suggest that such a high population enhances climatic variations by causing pressure on the existing natural resources, thus leading to environmental degradation, increased conflicts, food security, and high poverty levels as resources become scarce. Marchant and Lane [13] also point out a strong connection between increased human interventions and the region's ecosystem based on its historical perspectives, which significantly shapes its economic and social development. Indeed, there are already observed direct climate change impacts on the development of climate-dependent activities such as agriculture which account for $43 \%$ of the gross domestic product (GDP) of East Africa-and impacting the livelihood of $80 \%$ of the region's general population [14]. The following section will discuss the key vulnerability sectors in East Africa in detail.

\subsection{Key Sector Vulnerabilities to Climate Change}

This section will discuss the key sectors in East Africa that are most vulnerable to climate change. They include food security, water resources, biodiversity, human health and extreme weather events.

\subsubsection{Food Security}

One of the most widespread and devastating impacts of climate change in East Africa is food insecurity, with projections of frequent emergencies and famine as shown in Figure 1. As the UN Food and Agriculture Organization (FAO) reports, there is a strong link between climate change and East African food insecurity due to the shifts in growing seasons, interposed with increased droughts and floods that destroy food crops [15]. There has been a decline in the long rainfall season between March and May, and the progressive moisture deficit has resulted in decreased crop yield of long-life grains, such as maize, across the region [16]. Consequently, the low production of maize, which accounts for (13.1\% daily calories per capita in Burundi, (19.5 percent) Ethiopia, (9.3\%) Uganda, (25.7\%) Tanzania, $(33.3 \%)$ Kenya, significantly affects the available food supply [14]. Climate change also affects East Africa's fisheries, with many tropical fish such as tilapia unable to survive the increasing temperatures that are beyond their thermal maxima, thus affecting access to affordable food to the majority of populations along the lakesides [17]. 


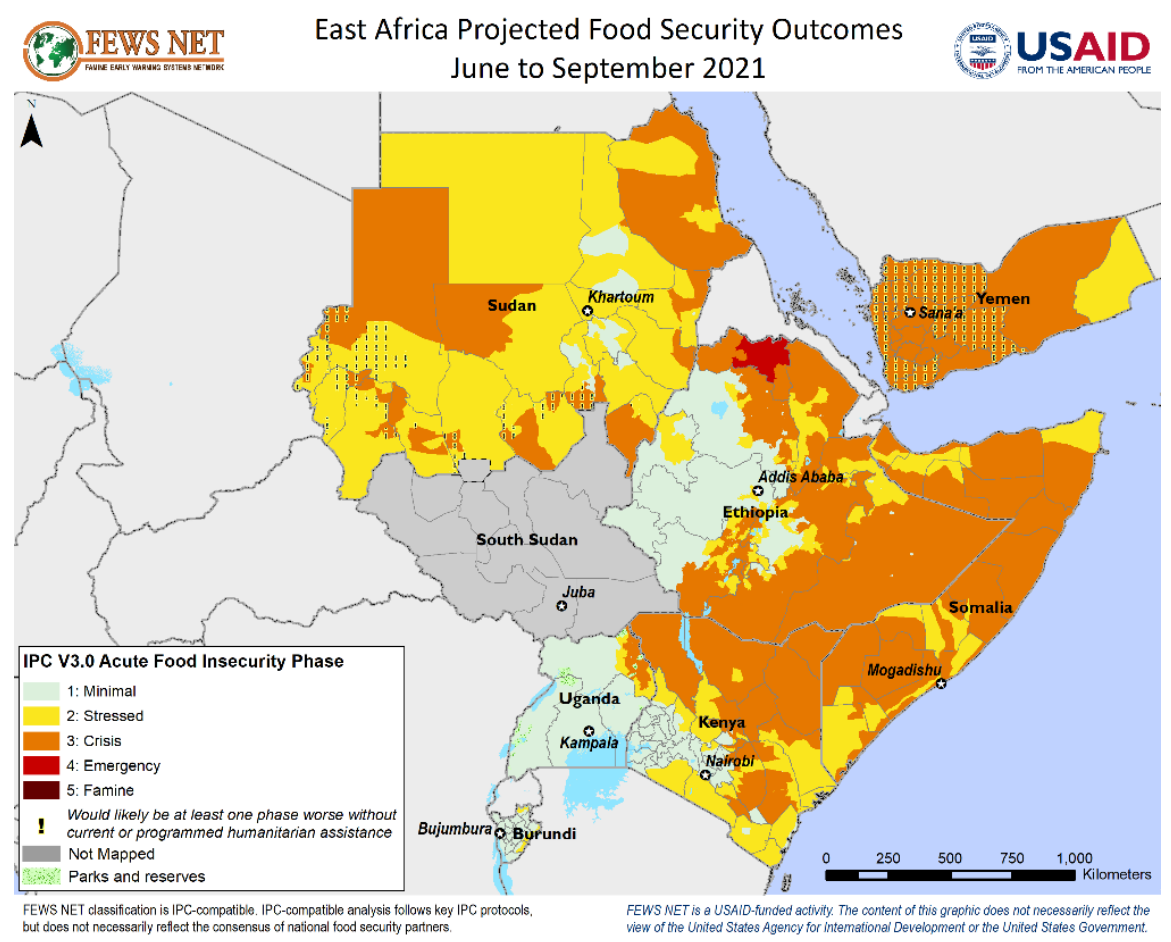

Figure 1. EA Projected Food Security Outcomes. Source: FEWS NET, April 2021. Available on: https: / / fews.net/east-africa (accessed on 2 June 2021).

\subsubsection{Water Resources}

Climate change has impacted the frequency, intensity, and predictability of precipitation in East Africa. IPCC [18] projects that the region will experience decreased rainfall of 20 percent in the dry seasons by 2050 . Thus, such changes in precipitation affect water availability and quality in East Africa's lakes and rivers that support the health and livelihoods of millions of people [19] while underpinning hydropower production and agricultural security [14]. Not only are these changes not uniform, but they also occur in widespread, unpredictable events. Accordingly, there have been abnormally high amounts of precipitation events across the equatorial part of East Africa, especially in the already wet seasons that add to erosion and complicate water management issues (ibid.). Less precipitation in the already dry season also enhances frequent and severe droughts and, ultimately, water scarcity [19]. Indeed, water availability for human consumption is of great concern, Grasham, Korzenevica and Charles [20], indicating that two-thirds of rural dwellers and a quarter of urban dwellers in East Africa lack access to clean water. The rising sea levels also enhance salt-water intrusion into river deltas and aquifers, thus threatening the availability of fresh water.

\subsubsection{Human Health}

Climate variability also significantly affects human health through heat stress, air pollution, water-borne diseases (typhoid, diarrhea, cholera) and vector-borne diseases (malaria, dengue fever) [21]. While other factors such as health preparedness and topography influence the spread of disease, scientists have established that high temperatures and intense rainfall provide critical breeding environments for the mosquitoes causing malaria [22]. Consequently, there have been increasingly reported malaria cases, especially in the highland parts of Kenya, Tanzania, Rwanda, Ethiopia, and Uganda [23]. The authors argue that the highlands that were previously the cooler areas of the region, had not previously been susceptible to malaria until climate change intensified. The number of people exposed to the disease is expected to double by 2070 (ibid.). Onyango, et al. [22] further assert that the cost of household expenditure for malarial treatments is highest in 
East Africa. Moreover, the rift valley epidemic is also a great threat to human health, and Bryson, et al. [23] reports that it mostly occurs during the extremely wet seasons in East Africa. Hence, such examples evidence that climate variability causes a high burden of disease to East Africans.

\subsubsection{Extreme Weather Events}

Extreme weather events such as droughts, floods and wildfires are now frequent events across East Africa, with their impacts varying across the region. For example, Wainwright, et al. [24] report that the recent short rain season of 2019 in East Africa was the wettest; it caused massive landslides and floods that affected approximately 2.8 million people. According to Figure 2, flooding further affected millions of East Africans in 2020, leaving many populations in need of humanitarian aid.

\section{FLOOD-AFFECTED AREAS}

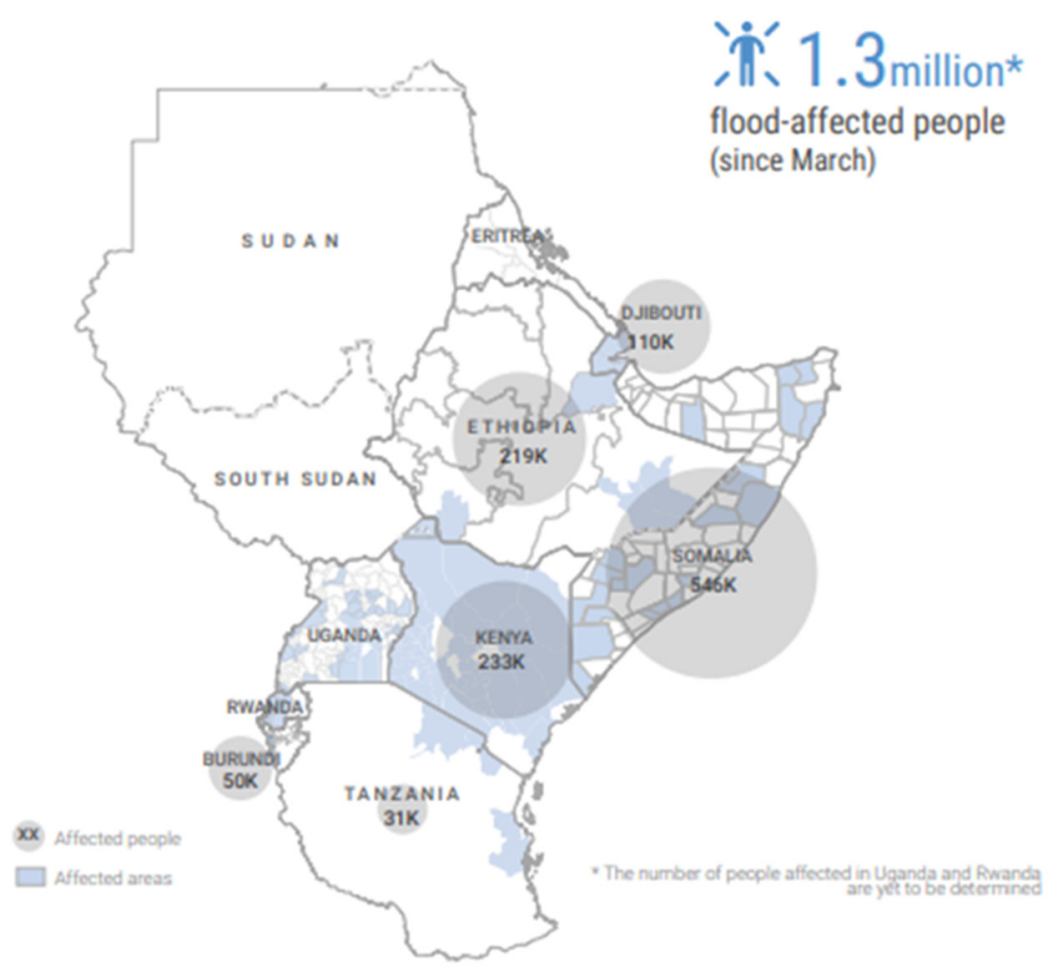

Figure 2. Flood impacts in East Africa. Source: UN OCHA, May 2020. Available online: https:/ / reliefweb.int/sites/reliefweb.int/files/resources/ROSEA_20200511_EasternAfrica_ Flood_Snapshot.pdf (accessed on 2 June 2021).

Climate variations also cause intense droughts that result in widespread famines and conflicts between humans and wildlife as they fight for scarce water resources [19]. In Sudan, for example, more than half of the country is a desert or semi-desert, and the decreased precipitations resulting from climate change have caused more desertification and other forms of land degradation. Regional lake level fluctuations as observed in Lake Victoria in Uganda, Kenya, Tanzania, and Burundi also enhance flooding and disrupt economic activities such as fisheries and tourism along the lakes [25]. Similar impacts occur due to sea-level rise, causing loss of coral reefs and mangroves, and ultimately coastal erosion along the Indian Ocean in Kenya and Tanzania [26].

\subsubsection{Biodiversity}

Sintayehu [27] points out that Africa remains one of the most under-studied continents regarding ecosystem dynamics and climate change. However, the impacts of climate variability on the region's rich biodiversity are already being felt. Historically, climate 
change has resulted in dramatic shifts in the geographical distributions of species and ecosystems in East Africa, particularly after the post glaciers period [21]. Extreme temperature rise combined with other stresses disrupts species' habitat and their co-existence. Maitima, et al. [28] suggest that East Africa is particularly vulnerable to invasive and exotic species colonization due to its sensitive fauna, resulting in numerous localized extinctions. Additionally, plant species that cannot keep up with the climate shifts, such as the shrub savannahs in East Africa that are highly sensitive to short-term water availability, are declining [27]. Climate change is also likely to alter species migration routes, such as the Wildebeests migration from Kenya to Tanzania, leading to population decline.

\subsection{Climate Change Response in East Africa}

To respond to the said phenomena, the East Africa Community developed a Climate Change Policy (EACCCP) in 2009 to implement measures to improve the region's adaptive capacity and resilience to the negative effects of climate change [29]. Most of the adaptation priorities in the policy tend to focus on livelihoods, energy, forests, agriculture and food security, disaster response, transport, and coastal zones. However, Price [30] argues that this vertical focus on specific sectors rather than horizontal cross-cutting linkages limit policy coherence. Apart from the policy, the region also established the Eastern Africa Climate Smart Agriculture Platform (EACSAP) in 2014, which seeks to promote agricultural productivity, adaptation, and resilience to climate change through technological innovation (ibid.). Additionally, East African countries have developed national climate change strategies, which are at various implementation stages. Table 1 illustrates country-specific climate policies in detail and the action points for their implementation.

Table 1. Climate Change policies in East Africa.

\begin{tabular}{|c|c|c|c|c|}
\hline Country & $\begin{array}{c}\text { Climate Change } \\
\text { Policy }\end{array}$ & Overarching Aims & Action Points & Link \\
\hline Burundi & $\begin{array}{c}\text { National Climate } \\
\text { Change Policy } \\
2012\end{array}$ & $\begin{array}{l}\text { Promote climate } \\
\text { resilient } \\
\text { development by } \\
\text { coordinating } \\
\text { environmental } \\
\text { restorative activities }\end{array}$ & $\begin{array}{l}\text { Integrate disaster risk reduction into } \\
\text { national development plans. } \\
\text { Strengthen institutional capacity to } \\
\text { respond to climate change } \\
\text { - Mobilize resources for climate } \\
\text { change adaptation } \\
\text { Establish early warning strategy for } \\
\text { climate change }\end{array}$ & $\begin{array}{l}\text { https: } \\
\text { // unfccc.int/sites/d } \\
\text { efault/files/resourc } \\
\text { e/BurundiTNCexec } \\
\text { utivesummary.pdf } \\
\text { (accessed on 25 May } \\
\text { 2021) }\end{array}$ \\
\hline Ethiopia & $\begin{array}{c}\text { Climate Resilient } \\
\text { Green Economy } \\
\text { (CRGE) strategy, } \\
2011\end{array}$ & $\begin{array}{c}\text { Keep greenhouse } \\
\text { emission low and } \\
\text { achieve } \\
\text { middle-income } \\
\text { status by } 2025\end{array}$ & $\begin{array}{l}\text { - } \quad \text { Reduce agricultural emissions } \\
\text { - } \quad \text { Protect and expand forests } \\
\text { - } \quad \text { Adopt energy efficient technologies in } \\
\text { transport, industry and the built } \\
\text { environment. }\end{array}$ & $\begin{array}{l}\text { https:/ / www.undp } \\
\text {.org/content/dam } \\
\text { /ethiopia/docs/Eth } \\
\text { iopiaCRGE.pdf } \\
\text { (accessed on 25 May } \\
\text { 2021) }\end{array}$ \\
\hline Kenya & $\begin{array}{c}\text { National Climate } \\
\text { Change Action } \\
\text { Plan 2018-2022 } \\
\text { (NCCAP) } \\
\text { National Climate } \\
\text { Change Policy, } \\
2018 \\
\text { Climate Change } \\
\text { Act, } 2016\end{array}$ & $\begin{array}{c}\text { Integrate climate } \\
\text { change into sectoral } \\
\text { planning and } \\
\text { implementation at } \\
\text { all levels } \\
\\
\text { Promote a climate } \\
\text { resilient and } \\
\text { low-carbon } \\
\text { economic } \\
\text { development } \\
\text { Mainstream climate } \\
\text { change into } \\
\text { sector functions }\end{array}$ & 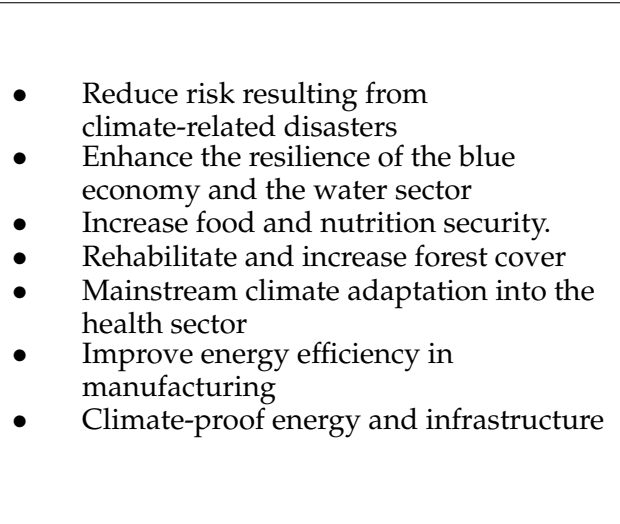 & $\begin{array}{c}\text { http: } \\
\text { //www.environmen } \\
\text { t.go.ke/wp-content } \\
\text { / uploads/2021/04 } \\
\text { /NCCAP-2018-2022 } \\
\text {-Abridged-Version- } \\
\text { August-14-2020.pdf } \\
\text { (accessed on 25 } \\
\text { May 2021) } \\
\text { http://kenyalaw.o } \\
\text { rg/kl/fileadmin/p } \\
\text { dfdownloads/Acts } \\
\text { /ClimateChangeAc } \\
\text { tNo11of2016.pdf } \\
\text { (accessed on 25 } \\
\text { May 2021) }\end{array}$ \\
\hline
\end{tabular}


Table 1. Cont.

\begin{tabular}{|c|c|c|c|c|}
\hline Country & $\begin{array}{c}\text { Climate Change } \\
\text { Policy }\end{array}$ & Overarching Aims & Action Points & Link \\
\hline Uganda & $\begin{array}{l}\text { Green Growth } \\
\text { Development } \\
\text { Strategy 2017-2030 } \\
\text { National Climate } \\
\text { change policy } \\
\text { (NCCP) } 2015\end{array}$ & $\begin{array}{l}\text { Achieve an inclusive } \\
\text { low-carbon } \\
\text { economic } \\
\text { development that } \\
\text { observes efficient } \\
\text { and sustainable use } \\
\text { of natural resources } \\
\text { and human capital } \\
\text { Attain } \\
\text { transformation } \\
\text { through climate } \\
\text { change mitigation } \\
\text { and adaptation }\end{array}$ & $\begin{array}{l}\text { - } \\
\text { Focus on natural capital management } \\
\text { and development } \\
\text { Plan the urbanization and development } \\
\text { of green cities } \\
\text { Develop sustainable transport systems } \\
\text { for urban areas } \\
\text { - Invest in renewable energy for } \\
\text { green growth } \\
\text { Facilitate the mobilization of resources to } \\
\text { address climate change impacts }\end{array}$ & $\begin{array}{c}\text { https://www.undp } \\
\text {.org/content/dam } \\
\text { /LECB/docs/pubs- } \\
\text { reports/undp-ndc-s } \\
\text { p-uganda-ggds-gree } \\
\text { n-growth-dev-strat } \\
\text { egy-20171204.pdf } \\
\text { (accessed on 25 } \\
\text { May 2021) } \\
\text { https: } \\
\text { / / www.mwe.go.ug/ } \\
\text { sites / default/files/1 } \\
\text { ibrary/NationalCli } \\
\text { mateChangePolicy } \\
\text { April2015final.pdf } \\
\text { (accessed on 25 } \\
\text { May 2021) }\end{array}$ \\
\hline Tanzania & $\begin{array}{l}\text { National Climate } \\
\text { Change Strategy } \\
\text { (NCCS) } 2012\end{array}$ & $\begin{array}{c}\text { Enhance Tanzania's } \\
\text { technical, } \\
\text { institutional and } \\
\text { individual capacity } \\
\text { of citizens to address } \\
\text { climate change } \\
\text { impacts }\end{array}$ & $\begin{array}{l}\text { Mobilize resources to adequately } \\
\text { address climate challenges } \\
\text { Enhance the resilience of ecosystems to } \\
\text { the changing climate } \\
\text { - } \quad \text { Create awareness and promote public } \\
\text { Participation in climate } \\
\text { adaptation activities } \\
\text { Establish institutional arrangements for } \\
\text { effective climate change response }\end{array}$ & $\begin{array}{c}\text { https: } \\
\text { //www.prevention } \\
\text { web.net/english/pr } \\
\text { ofessional/policies / } \\
\text { v.php?id=59982 } \\
\text { (accessed on } 25 \\
\text { May 2021) }\end{array}$ \\
\hline Somalia & $\begin{array}{l}\text { Somalia National } \\
\text { Adaptation } \\
\text { Programme of } \\
\text { Action (NAPA) } \\
2013 \\
\text { Environmental } \\
\text { and Climate } \\
\text { Change Policy } \\
2012\end{array}$ & $\begin{array}{c}\text { Reduce change } \\
\text { induced } \\
\text { vulnerabilities to the } \\
\text { poorest } \\
\text { communities who } \\
\text { depend on natural } \\
\text { resources } \\
\text { Identify the key } \\
\text { environmental } \\
\text { challenges and } \\
\text { opportunities } \\
\text { in Somalia }\end{array}$ & $\begin{array}{l}\text { - } \quad \text { Protect forests and improve land use } \\
\text { Develop a national water resources } \\
\text { management plan } \\
\text { - Strengthen disaster management } \\
\text { agencies }\end{array}$ & $\begin{array}{l}\text { https: } \\
\text { / /www4.unfcc.int/ } \\
\text { sites/NAPC/Count } \\
\text { ry\%20Documents /P } \\
\text { arties/som01.pdf } \\
\text { (accessed on 25 } \\
\text { May 2021) } \\
\text { https://sidaenviro } \\
\text { nmenthelpdesk.se/d } \\
\text { igitalAssets/1725/ } \\
\text { 1725294_environm } \\
\text { ent-policy-brief-som } \\
\text { alia-2012.pdf } \\
\text { (accessed on 25 } \\
\text { May 2021) }\end{array}$ \\
\hline Rwanda & $\begin{array}{c}\text { National } \\
\text { Environment and } \\
\text { Climate Change } \\
\text { Policy } 2019 \\
\\
\text { Rwanda Green } \\
\text { Growth and } \\
\text { Climate Resilience: } \\
\text { National strategy } \\
\text { for climate change } \\
\text { and low carbon } \\
\text { development } 2011\end{array}$ & $\begin{array}{c}\text { Achieve a clean and } \\
\text { healthy } \\
\text { environment, } \\
\text { resilient to climate } \\
\text { change for a high } \\
\text { quality of life } \\
\\
\text { Promote climate } \\
\text { resilience and green } \\
\text { development } \\
\text { through adaptation, } \\
\text { mitigation and } \\
\text { poverty reduction }\end{array}$ & $\begin{array}{l}\text { - } \quad \begin{array}{l}\text { Promote green economic transformation } \\
\text { - }\end{array} \text { Strengance a functional natural ecosystem } \\
\text { meteorological services } \\
\text { - } \quad \begin{array}{l}\text { Enhance climate change adaptation } \\
\text { mitigation and response }\end{array} \\
\text { Promote environmental well-being for } \\
\text { all citizens } \\
\text { - Strengthen environment and climate } \\
\text { change governance } \\
\text { Encourage green investment and other } \\
\text { capital inflows } \\
\text { Mobilise funding to finance climate } \\
\text { adaptation programs }\end{array}$ & $\begin{array}{l}\text { http:/ / www.fonerw } \\
\text { a.org/sites/default/ } \\
\text { files/RwandaNatio } \\
\text { nalEnvironmentan } \\
\text { dClimateChangePoli } \\
\text { cy2019.pdf (accessed } \\
\text { on 25 May 2021) } \\
\text { https:/ / cdkn.org/w } \\
\text { p-content/uploads / } \\
\text { 2010/12/Rwanda-G } \\
\text { reen-Growth-Strate } \\
\text { gy-FINAL1.pdf } \\
\text { (accessed on 25 } \\
\text { May 2021) }\end{array}$ \\
\hline
\end{tabular}


Table 1. Cont.

\begin{tabular}{|c|c|c|c|c|}
\hline Country & $\begin{array}{c}\text { Climate Change } \\
\text { Policy }\end{array}$ & Overarching Aims & Action Points & Link \\
\hline Sudan & $\begin{array}{l}\text { Sudan National } \\
\text { Adaptation } \\
\text { Plan } 2014\end{array}$ & $\begin{array}{l}\text { Provide a platform } \\
\text { for climate change } \\
\text { policy dialogue }\end{array}$ & $\begin{array}{l}\text { Promote institutional capacity to adapt } \\
\text { to climate change } \\
\text { Enhance climate risk management and } \\
\text { integration in all sectors and levels }\end{array}$ & $\begin{array}{l}\text { https:// www4.unf } \\
\text { ccc.int/sites/NAPC } \\
\text { /DocumentsNAP/ } \\
\text { NationalReports/Su } \\
\text { danNAP.pdf } \\
\text { (accessed on 25 May } \\
\text { 2021) }\end{array}$ \\
\hline South Sudan & $\begin{array}{c}\text { National } \\
\text { Environnent } \\
\text { Policy 2015-2025 }\end{array}$ & $\begin{array}{l}\text { To enhance the } \\
\text { protection, } \\
\text { conservation and } \\
\text { sustainable use of } \\
\text { natural resources. }\end{array}$ & $\begin{array}{l}\text { - } \quad \begin{array}{l}\text { Reduce community vulnerability to } \\
\text { climate change }\end{array} \\
\text { - } \quad \text { Promote reforestation and agroforestry } \\
\text { Establish early warning systems } \\
\text { for droughts } \\
\text { Promote climate-smart } \\
\text { agriculture techniques }\end{array}$ & $\begin{array}{c}\text { https://www.gove } \\
\text { rnment.nl/binaries } \\
\text { /government/docu } \\
\text { ments/publications } \\
\text { /2019/02/05/climat } \\
\text { e-change-profiles/S } \\
\text { outh+Sudan.pdf } \\
\text { (accessed on 25 } \\
\text { May 2021) }\end{array}$ \\
\hline
\end{tabular}

N/B This list excludes Eritrea and Djibouti as there was not adequate information on climate change frameworks in these countries.

Government research institutions in East Africa are equally actively involved in climate change adaptation initiatives. The Uganda Ministry of Water and the Kenya Agricultural Research Institute have established climate change units. The Ethiopian Institute of Agriculture Research is developing climate-resilient crop and livestock programs [31]. East African governments are also collaborating with universities to train climate change researchers and professionals, even though there is a lack of data on completed, ongoing projects and their impacts. In addition, regionally, the Inter-governmental Authority on Development (IGAD) which works across eight East African countries, established a climate prediction and application center that tackles climate-related security risks [30].

Non-governmental organizations across East Africa have also not been left out in the fight against the climate crisis. Various institutions are banding together cooperatively to conserve depleting resources and protect vulnerable populations' livelihoods. For instance, in Tanzania, conservation groups promote mangrove protection and coastal areas through reforestation with climate-smart species, integrated land-use planning, and resource use technology [26]. In Sudan, Practical Action Organization introduced cleaner energies, such as cooking stoves to rural women to reduce the dependence on firewood fuel, thus improving people's health and reducing the environment's burden [32]. The Sudanese government recently signed a green climate fund with the United Nations Development Fund to support its citizens with climate-resilient water and food security.

Despite these efforts, Addaney [11] observes that climate change in Africa is still regarded as a technical problem that requires specialized solutions, while Orindi and Murray [21] assert that East African countries continue to treat climate change separately from their broader development agenda. Perhaps, the governments feel the urgent need to tackle the pressing poverty challenges rather than climate change. In this regard, the future predicted climate change impacts, culminating in a host of challenges for adaptation due to economic constraints, a backdrop of governance and land tenure issues would severely affect the region's sustainable development [2,11,31]. Weisser, et al. [12] maintain that adaptation to climate change should not merely focus on new activities but instead strengthen existing livelihood coping strategies through knowledge empowerment and skills sharing. For this reason, Verburg, et al. [10] suggest coordinating efforts between the government, the private sector, the civil society, and community members to promote climate change education and innovation in East Africa for maximized implementation of the existing strategies.

\section{The Role of Education in Climate Change Management}

While the policies mentioned above and climate agreements have increased the attention to curb the negative impacts of climate shocks [11,33], the current efforts generally 
overlook education's role in equipping people with skills to deal with uncertain environmental futures. As the literature reveals [33-37], educating people on climate change is a vital measure to persuade populations at all community levels including school children, farmers, and the general population to play an active role in mitigation and adaptation action. Nikendei, Cranz and Bugaj [38] further reiterate that teaching students on climate change as a scientific issue of social importance prepares them for democratic participation as they decide and adopt positive environmental behaviors. Wachholz, Artz and Chene [39] emphasize the importance of empowering college students with the right information about global climate change, while Ochieng and Koske [40] suggest that primary and secondary students also need climate knowledge, as they will have to make climate policy decisions. Thus, they need to have an informed perspective.

Consequently, the role of multi-disciplinary research in the pressing climate change issue is beyond doubt [36]. It is time to actively consider knowledge creation and skill development via education to tackle climate change rather than addressing it from a policy viewpoint that entirely leaves governments with the sole responsibility of developing strategies to adapt to its impacts. Reid [41] posits that research for climate literacy is vital for producing citizens who understand the climate system and can utilize that knowledge in their engagements as active community members. Wangari Maathai, a global climate activist, also highlighted the fact that "You cannot protect the environment unless you empower people, you inform them, and you help them understand that these resources are their own, that they must protect them" [42] (p. 1). Hence, both formal and informal climate change education plays a critical role in empowering populations to understand actively climate science and the skills to adapt and respond to climatic shocks [33].

Additionally, climate justice movements, which garner increased attention in all forms of media, also offer much-needed informal education on the pressing issue [43]. From the Climate Strikes by Greta Thunberg to Idle No More and many activist projects that range in scale, these movements make visible the links between the environment and social justice $[44,45]$.

\section{Climate Change Education in East Africa}

It is evident that the continued extraction of natural resources for economic development is geographically and socially uneven, and so are the effects of climate change [4]. East Africa is one of the regions that is severely experiencing the adverse impacts of ever-changing climate due to its dependence on rain-fed agriculture and tourism as the backbone of its economies, sectors that are highly vulnerable to extreme climatic variations. From the recurring droughts in Djibouti, Sudan, and Ethiopia, the floods in Somalia, these climate-related events exacerbated food insecurity and human conflicts resulting from a scarcity of natural resources and ultimately forced migrations within the region $[10,16,31]$. Despite these increased phenomena, the impacts of climate change are still inadequately addressed over East Africa.

Assessing the role of education in addressing climate change issues in the region is of great importance. In Kenya, for example, most citizens are concerned about food insecurity issues and drought, a common phenomenon in the agriculture-dependent economy [46]. However, there is still some misinformation about the causes of climate change among the general population [47]. A study carried out among primary school teachers in western Kenya to assess their perception of climate change showed their concerns on climate change threats and existing challenges. Still, they lacked knowledge on clear strategies for climate mitigation and adaptation in their communities [40]. Silvestri, et al. [47] also reports a lack of adaptation knowledge as a behavioral barrier limiting some agriculture communities to respond to climate change effectively.

While there are broad and enduring questions regarding climate change education that this paper may not answer entirely, it will examine some key challenges and opportunities of climate change education in East Africa. Notably, the research will highlight the role of climate education in the region, who the critical players are, and the existing chal- 
lenges. It will also highlight the opportunities to reinforce formal and informal knowledge base to create a more comprehensive climate change awareness, adaptation policies, and implementation strategies that target all key stakeholders.

\section{Analysis and Findings}

This section presents key findings from the literature on the challenges for climate change education in East Africa to make recommendations for future action. We identify opportunities to overcome the barriers to action, and we describe approaches for addressing classroom and informal climate change education to promote behavior change by the general public. Lastly, we address the limitations of the literature review and summarize the critical steps of educating communities to be more resilient in the face of climate change.

Due to the broad perspective of the research topic, we adopted a narrative review involving basic key terms search to examine the challenges and opportunities for climate change education in East Africa. The material was derived from a comprehensive literature search from the Web of science and google scholar. The databases were searched using different permutations and combinations of key terms such as 'climate change, 'climate variability, 'environmental change,' 'climate change impacts,' 'education,' 'awareness,' 'East Africa,' 'Uganda,' 'Ethiopia,' etc. Since the study captured the diverse issues of climate change in the different country contexts in East Africa, the only typical inclusion and exclusion criteria were based on the dates of publication, originality, and language. The search covered full-text articles published from 2005 to 2021 to ensure that the issues discussed were current. We reviewed articles' abstracts to eliminate those that did not meet the goal and objectives of the study. After applying the above criteria, an estimate of 50 studies remained for in-depth content analysis. We also checked the reference list of relevant articles to ensure no relevant published articles on climate change education since 2005 were missed. Such flexibility in the literature used was critical to identify the gaps and opportunities for climate change education in the region. To evaluate the different climate change policies in East African countries and their relation to education, a google search on governments and the United Nations' website was conducted. We generated a table with the countries that have established climate change policies and strategies. On that basis, certain themes regarding the challenges and opportunities for climate change education in East Africa were developed and elaborated accordingly.

\section{Challenges of Climate Change Education}

The literature indicates that nations in East Africa are increasingly integrating climate change in their education curriculum due to the global crisis's mounting awareness [48,49], and with such integrations come many challenges to teach the topic. These include the need to ascertain the role of the educator, grappling with misconceptions, complexities of interdisciplinarity and understanding the content of climate change education.

\subsection{Ascertaining the Role of the Educator}

Firstly, it is not clear whether educators' role is limited to conveying climate science facts or extends to climate justice, which entails empowering their students with problemsolving skills to implement climate change projects within their communities [40]. Climate science teachers lack clear guidance on how and which aspects of climate change to pursue, and similar trends are evident globally. Berger, Gerum and Moon's [35] findings on bachelor of education programs in a university indicate that the teachers were not trained on the effective way to communicate about climate change. Many study participants also reported being reluctant to teach the topic because of its political nature, a common controversy even in East Africa. Educators' aggressive climate actions within their localities may also cause conflicts with community members who are keen to protect their identities as the topic of climate change greatly resonates with people's held values and ways of life [37]. For instance, there are conflicting interests and controversies concerning hazardous waste management; key decision-makers may feel that green development hampers productiv- 
ity. Their neoliberal ideas can over-rely on natural resources, thus attempting to recall information that reinforces their judgments [33]. Wise [50] also reports teachers' concerns about parents' responses regarding climate change, making them hesitant to teach the topic. They believe that teaching climate change in their communities could decrease their credibility and effectiveness [37]. Such perceptions are replicated in East Africa, where parents uphold exam-oriented learning for their children rather than teaching climate change topics, normally not tested in national examinations. Accordingly, teaching climate change's complexity and uncertainty requires careful thought and attention, hindering practical and strategic education about this global crisis.

\subsection{Grappling with Misconceptions}

The abounding misconception about the causes and effects of climate change among young people [39], local communities [34], and educators [35,40], also presents key barriers for conveying accurate climate science information through school programs and noninformal avenues. The Afifi, et al. [51] study on climate change perception among refugees in East Africa showed a lack of awareness, with many refugees blaming bad governance and conflict for the climatic problems. In Sudan, farmers acknowledged that the weather was increasingly changing; however, they reported economic challenges such as poverty rather than land-use changes to be a major cause of climate change [52]. For this reason, the farmers believed they had no capabilities to adapt to the climate phenomena. Similarly, Huho [49] asserted that many young people in Kenya believe that climate change is a problem that only affects farmers; thus, they find no value in learning about it. Despite the few studies, there is still inadequate research on climate knowledge and awareness among vulnerable populations, narrowing the appropriate educational strategies to tackle the existing gaps [47]. Further, the very design of climate education within the school curriculum and the compartmentalization of knowledge also poses a significant challenge for practical learning and climate change adaptation. Huho [49] reports that teaching climate change is commonly left to science teachers within the school setup; so is the replication of the syllabus in many schools in East Africa, limiting collective actions within school programs and the general population.

\subsection{Complexities of Interdisciplinarity}

Bangay and Blum [33] assert that most of the climate education materials focus on knowledge transfer without considering the content of climate education and how it interacts with other cross-cutting issues within communities. In Eastern African countries where populations' displacement is frequent such as South Sudan and Somalia, climate change is closely linked to land conflict and migration [12]. Thus, the lack of integration of such local challenges into climate science makes it impractical for many students and vulnerable communities in East Africa. The interdisciplinary nature of climate also translates to multiple knowledge gaps for most teachers due to the rapidly emerging scientific, political, ethical, and economic data [35]. Hence, this knowledge gap, linked with a lack of adequate content knowledge; perhaps because most teachers did not learn about climate change either in their schooling [36], means they may avoid teaching the topic. Hence, the lack of multidisciplinary teaching on climate change topics within the school syllabus eliminates fundamental aspects and successful mitigation actions to respond to climate change impacts. According to Nikendei, Cranz, and Bugaj [38], there is a need to teach climate change across all disciplines to address the many complexities of climate variability while providing opportunities to recognize social and scientific aspects. Pruneau, Khattabi, and Demers [34] also propose experiential teaching that fosters critical thinking and empowers students to reimagine different futures and develop the capacity to act to the climate crisis globally. 


\subsection{Understanding the Content of Climate Change Education}

Certain climatic and environmental notions are also numerous and complex; thus, non-specialist educators and the general population may find it challenging to understand all the global problem elements. Pruneau, Khattabi, and Demers [34] point to the intricacy of climate variability that results from the immense web of casual links between interdependent factors that affect each other in several ways. Similar complexities are also evident in East Africa, where high population growth is linked to climate change, which translates to food insecurity, displacements, further concentrated high populations in certain areas, and vice versa [12]. For these reasons, people view climate change as a set of complex problems that could keep citizens from teaching and learning the topic. Besides, some present-day impacts of climate change are difficult to perceive, either because they are invisible to the naked eye or in remote areas where people have little knowledge of the living conditions. For instance, the rising ocean temperatures along the Indian Ocean in Kenya and Tanzania and the extinction of animal species, such as the turtles in Somalia [27]. Pruneau, Khattabi, and Demers [34] report that not being able to perceive such problems curtails awareness of the climate crisis and, thus, the experiential learning that can enhance climate justice.

\section{Opportunities for Climate Change Education}

Irrespective of existing challenges, the literature captures a number of opportunities in East Africa that can be maximized for climate change education. Among these are overwhelming support from educators, the government's commitment, and the presence of indigenous knowledge systems.

\subsection{Overwhelming Support from Educators}

Teachers' overwhelming support of climate change education, despite the reports that very few have received training and lack adequate resources to teach the topic $[33,36,37,49]$, presents opportunities to empower them with the right knowledge about the matter. Ochieng and Koske [40] also posit that most teachers believe that climate change should be taught in schools, including individual actions and policies to deal with the climate crisis. Hence, it is essential to train educators on climate literacy's critical principles and scientific consensus on the causes of climate change to enlighten their students about the global problem effectively [36]. Huho [49] further asserts that with the right support and developed content of climate change education, populations can gain the right knowledge and dispel the many misconceptions of climate change. Moreover, having accurate information empowers vulnerable communities to take the most effective actions to mitigate the impacts of climate change. Nikendei, Cranz, and Bugaj [38] suggest that teaching should not precisely focus on explaining climate science but also create awareness of the impacts of climate change on humanity and the environment. For this case, schools can collaborate with youth movements and local organizations in East Africa who share positive messages to improve climate-related action and behavior change among local communities. For instance, Mukwano industries, one of the largest companies in Uganda, invest in treeplanting initiatives with small-holder farmers as part of its corporate responsibility [32]. However, some of these farmers may not have accurate information concerning climate change and agriculture; thus, educators' partnership with such organizations can fill the missing knowledge gap.

\subsection{Government's Commitment}

East Africa's government's commitment to creating a favorable regulatory and enabling environment to build resilient communities also provides relevant educational integration opportunities in their established national climate change policies. For instance, Rwanda has an environmental education for sustainable development strategy (EESD), which aims to create environmental awareness, complemented with ecological topics embedded in all its K-12 curricula to foster eco-friendly attitudes [48]. Such illustrations mean that climate education strategies exist. There is only a need to revitalize climate change 
information to be personally meaningful to learners while engaging them in planning and mitigation activities [37]. The policies should incorporate adequate funding to train educators and resource materials for climate change learning. Ethiopia and Kenya also have well-established agricultural research centers [31] that can be integrated into the higher education learning system to provide much-needed research on climate adaptation in the region [53]. As Henderson, et al. [36] propose, educational researchers working within diverse disciplines need to engage in the most pressing issues of climate variability. The research activities should actively involve young people and Indigenous communities to create comprehensive platforms for understanding and addressing climate change. Accordingly, the research institutions' existence within the East African region is a contingency for educators to incorporate participatory learning to offer holistic and transformative answers for climate change management.

\subsection{The Presence of Indigenous Knowledge Systems}

Moreover, combining Indigenous knowledge with formal research presents unique opportunities to empower vulnerable populations to mitigate and adapt to climate shocks. According to Songok [54], the lack of integrating Indigenous knowledge with scientific climate change response plans excludes local actors' participation in climate education. Speranza, et al. [55] also indicate that climate change education curricula in East Africa lack contextual relevance and devalue Indigenous knowledge due to the western teaching hegemony in the education system. Therefore, there is a need to promote locally based knowledge on climate change that communities can easily understand and apply to deal with climate variability [56]. Indeed, despite the arising debates regarding the accuracy of Indigenous knowledge systems as climate change continues in the future, small-scale farmers in East Africa are already utilizing their informal knowledge to adapt [31,46]. For instance, some agro-pastoralist communities in Kenya use various Indigenous knowledge indicators, such as weather variables, and environmental factors, such as the hills' shadow, to monitor climate variability [55]. The authors maintain that even locals with access to formal climate education still consult indigenous forecasts to plan their farming practices (ibid.). Such actions indicate that agro-pastoralists in East Africa use Indigenous knowledge as the background to position and interpret other sources of data for their climate adaptation practices. Moreover, Indigenous practices can improve climate monitoring, especially in rural areas in East Africa with few meteorological stations to access share and access information. Therefore, it is critical to reinforce formal and informal expertise to create a more comprehensive climate change awareness, adaption policies, and implementation strategies that target all key stakeholders to enhance sustainability.

\section{Recommendations for the Way Forward}

Educators clearly need additional training, resources, and time to adequately teach climate change in the classroom [35,36,49]. Educational ministries in East Africa can address this gap through organized training programs that focus on equipping teachers with crucial climate literacy principles. Governments should also provide teachers with resources such as lesson plans to incorporate this material in their classes. Foss and Ko [57] recommend professional development programs designed to help teachers integrate climate change education in their curriculum to ensure successful learning. On their end, educators should also acknowledge the seriousness and risk of climate change impacts within their communities, hence pass on locally relevant knowledge to their students. For example, teaching young students about rising sea levels within the desert areas in Sudan might not make sense; however, assimilating drought effects could enhance experiential learning. Monroe, et al. [37] also emphasize the essentiality of making climate change education meaningful to learners through technology that incorporates personal experiences. Strategies such as immersive virtual lessons enable students to see the longterm and geographically distant impacts of climate change, and consequently, the need to 
take mitigation actions [57]. An interdisciplinary approach that draws on expertise from various disciplines can also increase students' interest and understanding of the subject.

Additionally, encompassing climate change in all learning spaces, ranging from formal to informal, from the early years of schooling to the tertiary level, is the most coherent approach to leveraging education about the pressing issue. The East African community should incorporate quality learning, environmental and climate change education to promote relevant and multidisciplinary education that fosters critical thinking and problem-solving. Foss and Ko [57] maintain that all stakeholders' involvement encourages active and participatory learning to deliver the knowledge and skills relevant to the different local contexts. For instance, agricultural communities who are well-informed on Indigenous knowledge could be supported to enhance their adaptation practices rather than entirely introducing difficult scientific concepts of climate change which they might understand [54]. Similarly, strategies should also be adopted outside school settings, slowly building students' critical thinking about climate impacts, and supporting them to take climate actions through projects within their communities. For instance, parks and museums are suitable venues for child and adult education using craft activities that focus on positive change. Public meetings, such as the 'Barraza' (elders' gathering) that are common across Africa, could also be utilized as appropriate platforms to foster climate change discussions and resilience issues among the general public. Other professionals who shape the environment, such as urban planners, civil engineers and environmental researchers, should endeavor to be more active in climate education.

\section{Conclusions}

The literature review undertaken aimed to assess the challenges and opportunities for climate change education in East Africa. It achieved this by first highlighting the widespread impacts of the crisis and the global responses to this increasingly recognized phenomenon. The research also accentuated the importance of climate change education in managing its effects, especially regarding empowering vulnerable populations with the appropriate skills and knowledge to effectively adapt to extreme climates. Its originality lies in exploring whether and how climate change education is happening in East Africa while identifying existing opportunities to embed it with the current specific-country climate response plans. In addition to merely integrating climate change in educational curriculum as most East Africa governments currently do, the study identified the need to train teachers with accurate climate change information to make such knowledge meaningful to learners and incorporate Indigenous knowledge in the learning process.

The review process excluded some potential sources on climate change education, as we only captured the literature published in English and from Google Scholar and Web of Science database, with specific search terms. We acknowledge that relevant research or outputs that did not use the exact search terms that we employed would not have been captured in this review. While examining country-specific approaches to climate change education, we found the most inspiration from the general literature with a broader view on the barriers and opportunities of climate change education, which was aggregated with national climate change policies that mentioned the integration of the subject into the school curriculum. Hence, understanding the generality of these initial findings will be necessary for future endeavors regarding the topic. Further studies, therefore, that zoom into each of these key identified points are needed to gain a deeper understanding and establish more effective recommendations that target specific challenges. Despite these limitations, our study is based on diverse enough literature to offer meaningful insights and implications on the topic.

In conclusion, given the lack of well-defined leadership of climate change education in East Africa, various partnerships between government ministries, research groups in universities and institutions, local schools, museums, and non-profits could create better opportunities and place-based active learning on climate change. These approaches may also be necessary and useful outside East Africa, even within regions with clear climate 
education policies, as the misconceptions about the issue, exclusion of local knowledge, teachers' lack of adequate training, and definitions of their roles in climate change persist.

Although there may be practices in other continents that could be emulated in East Africa, we draw on Leal Filho and Hemstock [58] to argue that best approaches elsewhere may not be suitable in a different regional context as decisions about the most adequate practices should take into consideration local realities, available expertise, and resources.

Author Contributions: Conceptualization, A.A. and M.F.M.; writing—review and editing, A.A. and M.F.M. All authors have read and agreed to the published version of the manuscript.

Funding: This research received no external funding.

Conflicts of Interest: The authors declare no conflict of interest.

\section{References}

1. Melamed, M.L.; Schmale, J.; Von Schneidemesser, E. Sustainable policy—Key considerations for air quality and climate change. Curr. Opin. Environ. Sustain. 2016, 23, 85-91. [CrossRef]

2. Adenle, A.A.; Ford, J.D.; Morton, J.; Twomlow, S.; Alverson, K.; Cattaneo, A.; Cervigni, R.; Kurukulasuriya, P.; Huq, S.; Helfgott, A.; et al. Managing Climate Change Risks in Africa-A Global Perspective. Ecol. Econ. 2017, 141, 190-201. [CrossRef]

3. Lenton, T.M.; Rockstrom, J.; Gaffney, O.; Rahmstorf, S.; Richardson, K.; SteffenAU—Schellnhuber, H.; Schellnhuber, H.J. Climate tipping points-Too risky to bet against. Nature 2019, 575, 592-595. [CrossRef] [PubMed]

4. De Souza, K.; Kituyi, E.; Harvey, B.; Leone, M.; Murali, K.S.; Ford, J.D. Vulnerability to climate change in three hot spots in Africa and Asia: Key issues for policy-relevant adaptation and resilience-building research. Reg. Environ. Chang. 2015, 15, 747-753. [CrossRef]

5. United Nations. United Nations Climate. 2020. Available online: https://unfccc.int/process-and-meetings/the-convention/wha t-is-the-united-nations-framework-convention-on-climate-change (accessed on 23 February 2021).

6. Rosen, A.M. The Wrong Solution at the Right Time: The Failure of the Kyoto Protocol on Climate Change. Politi Policy 2015, 43, 30-58. [CrossRef]

7. Figueres, C. Paris taught me how to do what is necessary to combat climate change. Nat. Cell Biol. 2020, 577, 470-471. [CrossRef] [PubMed]

8. Dimitrov, R.S. The Paris Agreement on Climate Change: Behind Closed Doors. Glob. Environ. Politics 2016, 16, 1-11. [CrossRef]

9. United Nations. World Population Prospects. 2019. Available online: https://population.un.org/wpp/ (accessed on 22 February 2021).

10. Verburg, R.; Arets, E.; Verhagen, J.; Terwisscha van Schelting, C.; Ludwig, F.; Schils, R.; van Geene, J. Climate Change in East. Africa: Towards a Methodological Framework on Adaptation and Mitigation Strategies of Natural Resources; Alterra: Wageningen, The Netherlands, 2010.

11. Addaney, M. Climate change adaptation law and policy in the African Union: Creating legal pathways for adaptation. In Proceedings of the 5th International Climate Change Adaptation Conference, Cape Town, South Africa, 18-21 June 2018.

12. Weisser, F.; Bollig, M.; Doevenspeck, M.; Müller-Mahn, D. Translating the 'adaptation to cli-mate change' paradigm: The politics of a travelling idea in Africa. Geogr. J. 2014, 180, 111-119. [CrossRef]

13. Marchant, R.; Lane, P. Past perspectives for the future: Foundations for sustainable development in East Africa. J. Archaeol. Sci. 2014, 51, 12-21. [CrossRef]

14. Waithaka, M.; Nelson, G.C.; Thomas, T.S.; Kyotalimye, M. East. African Agriculture and Climate Change (a Comprehensive Analysis); International Food Policy Research Institute: Washington, DC, USA, 2013.

15. FAO. 2019 Africa Regional Overview of Food Security and Nutrition; FAO: Accra, Ghana, 2020.

16. Adhikari, U.; Nejadhashemi, A.P.; Woznicki, S. Climate change and eastern Africa: A review of impact on major crops. Food Energy Secur. 2015, 4, 110-132. [CrossRef]

17. Mohammed, E.Y.; Uraguchi, Z.B. Impacts of climate change on fisheries: Implications for food security in Sub-Saharan Africa. In Global Food Security; Nova Science Publishers, Inc: New York, NY, USA, 2013; pp. 114-135.

18. IPCC. Regional Climate Projections; IPCC: Geneva, Switzerland, 2018.

19. Haile, G.G.; Tang, Q.; Hosseini-Moghari, S.; Liu, X.; Gebremicael, T.G.; Leng, G.; Kebede, A.; Xu, X.; Yun, X. Projected Impacts of Climate Change on Drought Patterns Over East Africa. Earth's Futur. 2020, 8, 1-23. [CrossRef]

20. Grasham, C.F.; Korzenevica, M.; Charles, K.J. On considering climate resilience in urban water security: A review of the vulnerability of the urban poor in sub-Saharan Africa. Wiley Interdiscip. Rev. Water 2019, 6, e1344. [CrossRef]

21. Orindi, V.A.; Murray, L.A. Adapting to Climate Change in East Africa: A Strategic Approach; International Institute for Environment and Development (IIED): London, UK, 2005.

22. Onyango, E.A.; Sahin, O.; Awiti, A.; Chu, C.; Mackey, B. An integrated risk and vulnerability assessment framework for climate change and malaria transmission in East Africa. Malar. J. 2016, 15, 1-12. [CrossRef] [PubMed] 
23. Bryson, J.M.; Bishop-Williams, K.E.; Berrang-Ford, L.; Nunez, E.C.; Lwasa, S.; Namanya, D.B.; Harper, S.L. Indigenous Health Adaptation to Climate Change Research Team Neglected Tropical Diseases in the Context of Climate Change in East Africa: A Systematic Scoping Review. Am. J. Trop. Med. Hyg. 2020, 102, 1443-1454. [CrossRef] [PubMed]

24. Wainwright, C.M.; Finney, D.L.; Kilavi, M.; Black, E.; Marsham, J.H. Extreme rainfalls in East Africa. Weather. 2021, 76, 26-31. [CrossRef]

25. Akurut, M.; Willems, P.; Niwagaba, C.B. Potential impacts of climate change on precipitation over Lake Victoria, East Africa, in the 21st Century. Water 2014, 6, 2634-2659. [CrossRef]

26. Ojoyi, M.M.; Kahinda, J.-M.M. An analysis of climatic impacts and adaptation strategies in Tanzania. Int. J. Clim. Chang. Strat. Manag. 2015, 7, 97-115. [CrossRef]

27. Sintayehu, D.W. Impact of climate change on biodiversity and associated key ecosystem services in Africa: A systematic review. Ecosyst. Heal. Sustain. 2018, 4, 225-239. [CrossRef]

28. Maitima, J.M.; Mugatha, S.M.; Reid, R.S.; Gachimbi, L.N.; Majule, A.; Lyaruu, H.; Pomery, D.; Mathai, S.; Mugisha, S. The linkages between land use change, land degradation and biodiversity across East Africa. Afr. J. Environ. Sci. Technol. 2009, 3, 310-325.

29. East Africa Community. Climate Change Policy Framework. 2010. Available online: https://www.eac.int/environment/climatechange (accessed on 24 May 2021).

30. Price, R. Shared Governance of Climate Change and Natural Resources Issues in East Africa; K4D Helpdesk Report 450; Institute of Development Studies: Brighton, UK, 2018.

31. Nyasimi, M.; Radeny, M.; Kinyangi, J. Climate Change Adaptation and Mitigation Initiatives for Agriculture in East Africa; CCAFS Working Paper No. 60; CGIAR Research Program on Climate Change, Agriculture and Food Security (CCAFS): Copenhagen, Denmark, 2013.

32. Practical Action. Clearing the Air in Darfur. 2020. Available online: https://practicalaction.org/our-work/projects/clearing-the -air-in-darfur/ (accessed on 3 March 2021).

33. Bangay, C.; Blum, N. Education responses to climate change and quality: Two parts of the same agenda? Int. J. Educ. Dev. 2010, 30, 359-368. [CrossRef]

34. Pruneau, D.; Khattabi, A.; Demers, M. Challenges and Possibilities in Climate Change Education. US China Educ. Rev. 2010, 7, 15-24.

35. Berger, P.; Gerum, N.; Moon, M. “Roll up Your Sleeves and Get at It!” Climate Change Education in Teacher Education. Can. J. Environ. Educ. 2015, 20, 154-172.

36. Henderson, J.; Long, D.; Berger, P.; Russell, C.; Drewes, A. Expanding the Foundation: Climate Change and Opportunities for Educational Research. Educ. Stud. 2017, 53, 412-425. [CrossRef]

37. Monroe, M.C.; Plate, R.R.; Oxarart, A.; Bowers, A.; Chaves, W.A. Identifying effective climate change education strategies: A systematic review of the research. Environ. Educ. Res. 2019, 25, 791-812. [CrossRef]

38. Nikendei, C.; Cranz, A.; Bugaj, T.J. Two slides to make you think: 2slides4future, an initiative for teachers and lecturers advocating climate change education and teacher-learner dialogue. Med. Educ. 2020, 54, 467. [CrossRef] [PubMed]

39. Wachholz, S.; Artz, N.; Chene, D. Warming to the idea: University students' knowledge and attitudes about climate change. Int. J. Sustain. High. Educ. 2014, 15, 128-141. [CrossRef]

40. Ochieng, M.A.; Koske, J. The Level of Climate Change Awareness and Perception among Primary School Teachers in Kisumu Municipality, Kenya. Int. J. Humanit. Soc. Sci. 2013, 3, 174-179.

41. Reid, A. Climate change education and research: Possibilities and potentials versus problems and perils? Environ. Educ. Res. 2019, 25, 767-790. [CrossRef]

42. Zoeller, C. Conservation Hero: Wangari Maathai. 2021. Available online: https://www.oneearth.org/conservation-hero-wangari -maathai/ (accessed on 23 February 2021).

43. Schlosberg, D.; Collins, L.B. From environmental to climate justice: Climate change and the discourse of environmental justice. Wiley Interdisciplinary Reviews. Clim. Chang. 2014, 5, 359-374.

44. Porta, D.; Parks, L. Framing Processes in the Climate Movement: From Climate Change to Climate Justice; Methodologies of the commons. Routledge Handb. Clim. Chang. Mov. 2014, 1, 19-31.

45. Fisher, S. The emerging geographies of climate justice. Geogr. J. 2014, 181, 73-82. [CrossRef]

46. Kristjanson, P.; Neufeldt, H.; Gassner, A.; Mango, J.; Kyazze, F.B.; Desta, S.; Sayula, G.; Thiede, B.; Förch, W.; Thornton, P.K.; et al. Are food insecure smallholder households making changes in their farming practices? Evidence from East Africa. Food Secur. 2012, 4, 381-397. [CrossRef]

47. Silvestri, S.; Bryan, E.; Ringler, C.; Herrero, M.; Okoba, B. Climate change perception and adaptation of agro-pastoral communities in Kenya. Reg. Environ. Chang. 2012, 12, 791-802. [CrossRef]

48. Muhirwa, F. Environmental Education Profile in Rwanda; Protestant Institute of Arts and Social Sciences, Department of Natural Resources and Environmental Management: Huye, Rwanda, 2020.

49. Huho, J.M. Climate Change Knowledge Gap in Education System in Kenya. Int. J. Innov. Res. Educ. Sci. 2015,2 , $2349-5219$.

50. Wise, S.B. Climate Change in the Classroom: Patterns, Motivations, and Barriers to Instruction Among Colorado Science Teachers. J. Geosci. Educ. 2010, 58, 297-309. [CrossRef]

51. Afifi, T.; Govil, R.; Sakdapolrak, P.; Warner, K. Climate Change, Vulnerability and Human Mobility: Perspectives of refugees from the East and Horn of Africa; UNHCR: Geneva, Switzerland, 2012. 
52. Mertz, O.; Mbow, C.; Reenberg, A.; Diouf, A. Farmers' Perceptions of Climate Change and Agricultural Adaptation Strategies in Rural Sahel. Environ. Manag. 2009, 43, 804-816. [CrossRef]

53. Hill, P.; Worsfold, N.; Nagy, G.J.; Filho, W.L.; Mifsud, M. Climate change education for universities: A conceptual framework from an international study. J. Clean. Prod. 2019, 226, 1092-1101. [CrossRef]

54. Songok, C.K.; Kipkorir, E.C.; Mugalavai, E.M. Integration of Indigenous Knowledge Systems into Climate Change Adaptation and Enhancing Food Security in Nandi and Keiyo Districts, Kenya. In Climate Change Management; Springer Science and Business Media: Berlin, Germany, 2011; pp. 69-95.

55. Speranza, C.I.; Kiteme, B.; Ambenje, P.; Wiesmann, U.M.; Makali, S. Indigenous knowledge related to climate variability and change: Insights from droughts in semi-arid areas of former Makueni District, Kenya. Clim. Chang. 2009, 100, 295-315. [CrossRef]

56. Mbah, M.; Ajaps, S.; Molthan-Hill, P. A Systematic Review of the Deployment of Indigenous Knowledge Systems towards Climate Change Adaptation in Developing World Contexts: Implications for Climate Change Education. Sustainability 2021, $13,4811$. [CrossRef]

57. Foss, A.W.; Ko, Y. Barriers and opportunities for climate change education: The case of Dal-las-Fort Worth in Texas. J. Environ. Educ. 2019, 50, 145-159. [CrossRef]

58. Leal Filho, W.; Hemstock, S. (Eds.) Climate change education: An overview of international trends and the need for action. In Climate Change and the Role of Education; Springer: Cham, Switzerland, 2019; pp. 169-187. 